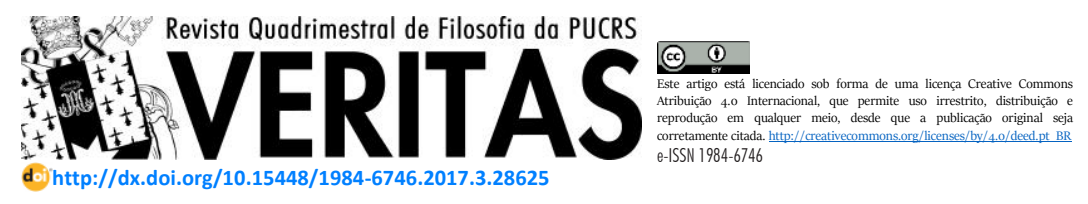

\title{
O lugar do testemunho na estrutura do conhecimento e da justificação
}

\author{
The place of Testimony in the \\ Fabric of Knowledge and Justification
}

\author{
Robert Audi \\ Tradução de Kátia Martins Etcheverry² \\ e Carlos Augusto Sartori ${ }^{3}$
}

\begin{abstract}
Resumo: ${ }^{4} \mathrm{O}$ objetivo central neste artigo é o de explicar o que é testemunho e como ele produz conhecimento e justificação. Conforme essa concepção, o testemunho é uma importante e habitual fonte de conhecimento e de justificação, bem como um conceito relevante em epistemologia social, comunicação e psicologia da aquisição de crença. Apesar de o testemunho, nessa concepção, não ser considerado uma fonte básica de conhecimento e justificação, é alegado que ele é uma fonte de conhecimento básico pois crenças básicas não precisariam derivar de uma fonte básica. Assim, novas crenças podem ser geradas a partir do testemunho, mas novo conhecimento não pode ser produzido a não ser a partir de conhecimento anterior. Apesar disso, a posição defendida neste artigo considera que, mesmo que a justificação com base no testemunho seja, em última instância, dependente de outras fontes de justificação, o testemunho constitui uma fonte essencial tanto de conhecimento como de justificação.
\end{abstract}

Palavras-chave: Testemunho; Fontes de conhecimento; Fontes de justificação; Crença testemunhal.

\begin{abstract}
This paper's central purpose is to offer an account of what testimony is and of how it yields knowledge and justification. According to the view presented here, testimony is a significant and common source of justification and knowledge, as well as an important concept in social epistemology, communication and the psychology of belief acquisition. Although in this perspective testimony is not treated as a basic source of knowledge or justification, it is considered as a source of basic belief since, it is argued, basic beliefs need not derive from a basic source. Thus, new beliefs can be generated on the basis of testimony, but new knowledge cannot be produced except by building on prior knowledge. Yet, the position defended in this paper is that, even if testimony-based justification is ultimately dependent on other sources of justification, it is an essential source of both knowledge and justification.
\end{abstract}

Keywords: Testimony; Sources of Knowledge; Sources of Justification; Testimonial beliefs.

\footnotetext{
1 "The place of Testimony in the Fabric of Knowledge and Justification", American Philosophical Quarterly, v. 34, p. 402-422, 1997. Tradução autorizada pelo editor-chefe da APQ e pelo autor.

${ }^{2}$ PPGF/PUCRS (CAPES) < katia.etcheverry@acad.pucrs.br>

3 Doutor em filosofia pela PUCRS. Professor de filosofia na Universidade Federal de Santa Maria. <carlos.augusto.sartori@gmail.com>
}

${ }^{4}$ N.T. Abstract, keywords e sua versão em língua portuguesa são de autoria dos tradutores uma vez que o original não contém estes itens. 
O testemunho é uma fonte disseminada e indispensável de justificação e conhecimento, e talvez seja tão importante para a teoria da comunicação e para psicologia de aquisição de crença quanto o é para a epistemologia. O testemunho é uma questão central para a epistemologia social, pela qual os filósofos têm mostrado crescente interesse. Mas, excetuando-se um pequeno número de valiosas discussões dedicadas ao testemunho nos últimos quinze anos, ${ }^{5}$ este permanece um tópico bastante secundário em epistemologia. Tal tratamento não é nem adequado à sua importância epistemológica, nem desejável do ponto de vista de uma explicação abrangente de conhecimento e justificação. Uma explicação de testemunho pode esclarecer tanto os fundamentos sociais como os individuais da crença. Pode também ressaltar as principais diferenças entre dois conceitos epistêmicos centrais, frequentemente relacionados de modo estreito: conhecimento e justificação. Inicio esboçando a natureza e abrangência do testemunho, e na sequência examino sua psicologia, seu status epistêmico e seu lugar na cognição humana.

\section{Testemunho formal e informal}

A palavra 'testemunho' comumente evoca imagens de uma sala de tribunal, onde alguém presta juramento ao depor, oferecendo informação que supostamente representa conhecimento ou crença. Com frequência, tal testemunho relata o que foi presenciado diretamente, mas o testemunho pode ser sobre algo que não é presenciado, como é o caso de implicações de uma teoria científica. ${ }^{6} \mathrm{O}$ testemunho formal, no entanto, não é do tipo básico (se de fato existir um tipo básico). O testemunho formal se diferencia do tipo informal pelas condições de sua expressão, mas não necessariamente por sua credibilidade. O testemunho do tipo

\footnotetext{
${ }^{5}$ Entre esses estão C. A. J. Coady, Testimony (Oxford: The Clarendon Press, 1992); B. K. Matilal e A. Chakrabarti, eds., Knowing from Words (Dordrecht: Kluwer, 1994); Fred Dretske, "A Cognitive Cul-de-Sac," Mind 81 (1982); Elizabeth Fricker, "The Epistemology of Testimony," Proceedings of the Aristotelian Society Supplementary Vol. 61 (1987) e "Against Gullibility," in Matilal e Chakrabarti; John Hardwig, "Epistemic Dependence," Journal of Philosophy LXXXII, 7 (1985); Ernest Sosa, "Testimony and Coherence," em seu Knowledge in Perspective (Cambridge: Cambridge University Press, 1991); Alvin Plantinga, Warrant and Proper Function (Oxford: Oxford University Press, 1993); Mark Owen Webb, "Why I Know about As Much as You," Journal of Philosophy XC (1993) (em parte uma crítica a Hardwig); e Jonathan E. Adler, "Testimony, Trust, Knowing," The Journal of Philosophy 91 (1994) (em parte uma crítica a Webb).

${ }^{6}$ Para uma explicação ampla e historicamente informativa do que constitui o testemunho e de numerosos problemas epistemológicos pertinentes, ver Coady, op. cit.
} 
amplo de que me ocupo aqui, - grosso modo, dizer ou afirmar algo em uma aparente tentativa de transmitir informação (correta) - é aquele que dá origem à questão sobre a importância do testemunho para o conhecimento e a justificação. ${ }^{7}$

Quando aplicado ao fornecimento casual de informação, como quando dizemos onde estávamos na noite passada, 'testemunho' é um termo muito forte. Poderíamos falar aqui de 'informar', mas isso é muito estreito, podendo tanto sugerir uma mensagem preparada (como em 'Ontem ela me informou de sua [dela] intenção') quanto em (normalmente) implicar sua verdade. Podemos considerar todo testemunho como sendo um tipo de dizer, mas nem todo dizer - mesmo desconsiderando-se o que é dito em ficção - é testemunho. Alguém que diz 'Ah, que árvore linda!' está expressando uma percepção da beleza da árvore, mas não está dando um testemunho de que ela é linda.

Proponho usar o termo atestar como uma rubrica ampla das declarações, orais ou escritas, de que estamos nos ocupando. Esse termo inclui tanto o testemunho formal de que algo é o caso, quanto o simples dizer, de modo informacional relevante, que algo é o caso, e também captura a ideia de dizer algo para alguém. Testemunho é sempre algo dado a uma ou mais pessoas (a si próprio, talvez, num caso limite), mas a audiência pode ser hipotética: alguém que escreve em seu diário, descrevendo atrocidades para a posteridade, pode não saber se alguém irá ler seu testemunho. O que devemos entender é o papel de todos esses tipos de testemunho - grosso modo, de pessoas nos dizendo coisas - ao explicar conhecimento e justificação. Quero começar com o modo como o testemunho produz crença; seu papel psicológico na cognição é ao mesmo tempo intrinsecamente interessante e epistemologicamente importante.

\section{A Psicologia do Testemunho}

Se começarmos enfocando o testemunho formal, podemos concluir que o testemunho, como fonte de crença, é muito diferente da percepção na medida em que o testemunho produz apenas crenças

\footnotetext{
7 Talvez o 'testemunho' possa se aplicar quando o falante não parece nem mesmo se importar em transmitir informação, mas está espontaneamente descrevendo de uma maneira detalhada e conectada eventos passados que testemunhou, retratando-os com exatidão. Talvez dizer algo possa contar como testemunho na medida em que é, de certo modo, apropriado para transmitir informação. Não precisamos de uma análise detalhada aqui, e a rápida caracterização sugerida no texto não negligencia nenhuma questão importante.
} 
inferenciais a partir do que é dito, enquanto que a percepção comumente produz crenças não-inferenciais sobre o que é percebido. A ideia de que crenças baseadas no testemunho são produzidas por inferência a partir de uma ou mais premissas é, provavelmente, natural em relação ao testemunho formal. Quando ouço um testemunho em tribunal, avalio a testemunha, coloco o testemunho no contexto do julgamento e de meu conhecimento geral, e aceito o que é dito apenas se ele me parece verdadeiro a partir desta perspectiva ampla. Não creio, simplesmente, no que ouço; creio nisso apenas com base em certas premissas, como a de que a testemunha parece sincera e de que o testemunho em questão se encaixa no que sei sobre o caso. ${ }^{8}$

Nesse quadro inferencialista do testemunho, ele, aparentemente, não é uma fonte de crença tão direta quanto a percepção: o testemunho produz crença através do próprio testemunho juntamente com uma ou mais premissas que apoiem a proposição afirmada ou que apoiem pelo menos a credibilidade do declarante. ${ }^{* * * *}$ Sendo assim, o testemunho também não é uma fonte tão direta de conhecimento ou justificação; pois alguém saberá ou estará justificado em crer, no que é afirmado somente se souber ou pelo menos estiver justificado em crer na(s) sua(s) premissa(s). Essa pessoa não obteria conhecimento simplesmente a partir do testemunho; ela dependeria também de premissas sobre o próprio testemunho. ${ }^{9}$

Outra descrição, provavelmente mais plausível, também pode explicar o papel psicológico de crenças já disponíveis. Nessa descrição, crenças sobre a credibilidade do declarante e crenças pertinentes à proposição afirmada podem desempenhar um papel de filtro: elas impedem que creiamos em um testemunho que não "passa", porque, por

\footnotetext{
${ }^{8}$ Confrontar com a tese de Fricker em "Against Gullibility”: "um ouvinte deve sempre realizar alguma avaliação da confiabilidade do falante. Crer no que é afirmado sem ter feito isso é ... credulidade” (p. 145); e sua referência ao conhecimento através do testemunho como sendo conhecimento inferencial "no sentido em que deve ser amparado por uma justificação substancial", (p. 156) (apesar de que "monitorar os sinais de falta de confiabilidade em um falante é usualmente conduzido em um nível não consciente" - p. 15o). A concepção de que o conhecimento baseado no testemunho é inferencial não é nova - ou restrita à filosofia ocidental: "Voltando-nos para o lado indiano clássico ... As duas tradições filosóficas bem estabelecidas, a Vaisesika e a Budista, permitem conhecimento a partir das palavras ... mas o incluem sob inferência." Ver B. K. Matilal, "Understanding, Knowing and Justification” em Matilal e Chakrabarti, op. cit., p. 359.

${ }_{9}$ Para conhecimento e crença justificada penso que a crença em questão deve estar baseada, em um sentido parcialmente causal, no testemunho relevante. Defendo este ponto para casos relevantemente similares em "The Causal Structure of Indirect Justification”, The Journal of Philosophy, 8o, (1983).
}

${ }^{* * * * *}$ NT. Optamos por traduzir 'attester', que se refere à pessoa que profere o testemunho, por 'declarante'. 
exemplo, parece insincero; mas, se nenhuma dificuldade desse tipo nos ocorre, nós "simplesmente cremos" (não-inferencialmente) no que é afirmado. Essas crenças-filtro são como uma arapuca que fecha apenas quando acionada; sua posição normal é aberta, mas está sempre pronta para bloquear o que não deve entrar. ${ }^{10} \mathrm{~A}$ posição aberta é uma espécie de confiança. A ausência de crenças-filtro, ou sua falta de rigor, produz credulidade; rigor excessivo produz ceticismo. Pode acontecer que tanto a abordagem de crenças-filtro como a de crenças inferenciais se apliquem, mas em diferentes circunstâncias (embora crenças não sejam os únicos elementos psicológicos que podem bloquear certas proposições afirmadas). As possibilidades psicológicas aqui são muito numerosas para serem detalhadas, mas é suficiente entender que a crença baseada no testemunho não precisa ser inferencial, isto é, não precisa ser baseada em uma crença ulterior de que o declarante proferiu algo de modo plausível.

No caso de um testemunho informal - o tipo mais comum - as crenças produzidas no ouvinte são tipicamente não-inferenciais. Normalmente, quando amigos de confiança falam conosco sobre questões que não supomos estar além de suas competências, simplesmente cremos no que nos dizem. De fato, se basicamente confio na palavra das pessoas, então, normalmente, quando alguém me diz algo, formo a crença no que foi dito; hesito apenas se (por exemplo) uma nova crença entra em conflito com uma ou mais crenças que já se encontram no meu sistema de crenças. ${ }^{11}$ Se você parece saudável e me diz que andou recentemente quarenta e oito quilômetros, ${ }^{* * * * *}$ posso prontamente acreditar em você, enquanto que, na ausência de uma evidência especial, eu não creria em alguém que alegasse ter subido o monte Everest sem cordas. A partir das crenças que já disponho, este feito é virtualmente impossível.

Do mesmo modo como é enganador construir uma explicação da psicologia do testemunho a partir de casos formais, é um erro assumir

\footnotetext{
${ }^{10}$ Reid falou eloquentemente sobre isto: "O sábio autor da natureza implantou na mente humana uma propensão a confiar no testemunho humano antes de podermos dar uma razão para assim fazer. Isso, de fato coloca nosso julgamento quase inteiramente nas mãos daqueles que se ocupam de nós no primeiro período da vida”. Ver Essay on the Intellectual Powers of Man, em Thomas Reid's Inquiry and Essays, editado por Ronald Beanblossom e Keith Lehrer (Indianapolis: Hackett, 1983), p. 281.

${ }^{11}$ Não afirmo ter estabelecido de modo decisivo esses pontos (empíricos) sobre a estrutura da crença baseada no testemunho, mas eles são psicologicamente plausíveis e certamente consistentes com o conceito de tais crenças. Considerações em apoio a isso são fornecidas por Webb, op. cit.
} 
uma concepção momentânea (sincrônica) de como o testemunho produz crença, mesmo em casos não-inferenciais. Nossas crenças atuais, e mesmo nossos processos de formação de crença, podem mudar no curso da recepção de um testemunho, e uma crença baseada no testemunho pode surgir diacronicamente. Suponhamos que eu encontre uma pessoa em um avião, e que ela me diga que um palestrante que eu conheço perdeu a calma durante uma conferência. Inicialmente suspendo o juízo a respeito do acontecido. Coisas assim são raras, e não conheço a pessoa [declarante]. Então, ela me descreve a conferência e outros detalhes começam a se encaixar, ela me confirma informações que já possuo, tais como quem se encontrava presente. Logo começo a ouvi-la com uma atitude de aceitação, formando crenças sobre cada coisa que ela me diz. No final, me vejo agora crendo que o palestrante de fato perdeu a calma. Neste caso minha crença baseada no testemunho é formada consideravelmente depois de eu ter ouvido o testemunho que lhe dá base.

Mesmo quando, inicialmente, a pessoa me relata que ele perdeu a calma, não precisei ter inferido (por exemplo) que eu deveria suspender o juízo sobre este proferimento improvável; suspensão de juízo (ou simples não-crença) pode ser uma resposta não-inferencial a limitações impostas por minhas crenças independentes. Ademais, seu testemunho é neutralizado, mas não é derrotado, por minhas crenças e impressões anteriores: elas me impedem de crer no que é afirmado; mas não invalidam uma crença que eu tenha formado com base no testemunho e da qual tenha desistido, como quando descubro que a crença é inconsistente com fatos aparentes. Na medida em que a narrativa dela avança, as limitações impostas por minhas crenças independentes enfraquecem; e, para cada uma de suas afirmações, formo crenças ao mesmo tempo de modo não-inferencial e espontaneamente, no sentido em que não ocorre nenhuma limitação que poderia ter entrado em operação: suas afirmações não têm mais de passar pelo filtro de meu escrutínio crítico, nem são filtradas por qualquer outra checagem quase automática que a mente faz rotineiramente quando as pessoas nos oferecem alguma informação.

O caso também parece mostrar algo que ultrapassa a questão de que testemunho pode produzir crença após o fato. Nesse caso, talvez a coisa mais difícil de explicar seja por que, ao final do testemunho dela, passo a crer na proposição que inicialmente tinha sido objeto de suspensão 
de juízo. Uma hipótese é a de que há uma inferência inconsciente: a partir da credibilidade geral de seu relato, chega-se à conclusão de que essa proposição, que é uma parte essencial dele, é verdadeira. Mas esse tipo de inferência não parece adequado ao caráter por vezes global do tipo de formação de crença em questão. Ainda que alguma explicação inferencialista possa dar conta satisfatoriamente dos dados, não há necessidade de apelar para inferência. A influência cognitiva das crenças já estabelecidas, tais como a crença recém formada de que a pessoa é confiável, não precisa provir de uma inferência a partir de qualquer subconjunto dessas crenças já estabelecidas. Existe uma explicação mais moderada sobre a formação da crença, que postula menos eventos conscientes e também, presumivelmente, menos gasto de energia mental. $\mathrm{O}$ fato de a pessoa em questão finalmente me parecer credível pode, de modo bastante direto, produzir em mim uma disposição geral para crer nela, mesmo sem ter de considerar um ou mais fundamentos para crer de modo geral nela, ou para aceitar o que ela diz, e mesmo sem que eu forme qualquer crença sobre sua competência quanto ao tópico da proposição afirmada. Essa disposição é reforçada na medida em que a pessoa me fala de maneira evidentemente credível, vencendo ao final a minha resistência em crer no que me é dito, que era exercida antes por minhas crenças limitadoras. Passo a confiar nela quanto ao assunto em questão.

Existem outras possibilidades (relacionadas), [pois] crenças podem mudar de muitas maneiras. Talvez as pessoas (ou alguns de nós) tenham uma escala de credibilidade na qual as pessoas que afirmam algo adquirem - usualmente sem nossa atenção consciente à questão - um lugar que pode mudar, também sem nossa atenção consciente. Essa é uma interessante hipótese empírica que não posso desenvolver aqui, mas o ponto crucial é ver como crenças com base testemunhal (que também podem ser chamadas de crenças testemunhalmente fundadas) podem ser limitadas por outras crenças sem serem inferencialmente baseadas nelas, e como crenças baseadas no testemunho podem ser formadas depois da afirmação que é sua fonte última. A percepção também pode produzir crença depois de seu momento inicial ou, com o auxílio da memória, depois de ser interrompida. Uma pessoa pode olhar uma forma à distância por um longo tempo antes de crer que é um tronco de árvore e não um passante que parou para olhar o céu. Essa mesma crença pode surgir muito mais tarde, a partir de uma imagem vividamente lembrada, quando 
a pessoa é inquirida como testemunha da cena. A conexão em virtude da qual uma crença está baseada em uma fonte não precisa ser direta, nem simultânea, e nem mesmo o resultado de uma inferência.

Pode a analogia com a percepção dar suporte à conclusão de que o testemunho, como a percepção, é uma fonte básica de crença, no sentido em que, grosso modo, ele pode produzir crença sem a cooperação de outra fonte de crença? Consideremos o caso da percepção. Se vejo um quadro, isso pode produzir em mim uma crença de que há um quadro diante de mim, sem que eu tenha qualquer outro tipo de experiência potencialmente produtora de crença, tal como uma consciência adicional da imagem de uma pintura. ${ }^{12}$ Mas não posso formar uma crença baseada no testemunho a menos que eu ouça (ou perceba de outro modo) o testemunho. A percepção é crucial para a formação de crenças testemunhais ao passo que nenhuma outra fonte de crença o é para a formação de crenças perceptuais. ${ }^{13}$ É claro que a percepção não produz crença sem condições prévias apropriadas, e tampouco o fato de ser uma fonte básica de crença implica que crenças prévias sejam irrelevantes para o status epistêmico de crenças perceptuais. Se creio firmemente que estou tendo uma alucinação da lua, então, mesmo se eu a vejo realmente, posso suspender o juízo sobre se ela já surgiu.

Embora o poder gerador de uma fonte básica não seja derivado de outra fonte, a fonte básica não é completamente independente de outras fontes ou de seus resultados. ${ }^{14}$

\footnotetext{
${ }^{12}$ É claro que preciso ter (e assim reter na memória) um conceito de pintura; mas esse mero estado de memória conceitual não é uma fonte potencial de crença (o que não significa dizer que ele não desempenhe nenhum papel causal na formação da crença).

${ }^{13}$ Três pontos podem ajudar aqui. Primeiro, a telepatia e outras recepções estranhas de testemunho, pelo menos para nossos objetivos, podem ser concebidas como sendo perceptuais. Em segundo lugar, aceitar que uma pessoa não possa formar crenças perceptuais sem ter algumas crenças adicionais, necessárias para a posse dos conceitos exigidos para a compreensão da proposição perceptual objeto de crença, não implica o tipo de dependência de outra fonte de crença tal como o do testemunho sobre a percepção. Em terceiro lugar, supondo que a percepção não possa ocorrer sem algumas manifestações na consciência (a qual é por si só uma fonte de crenças), aqui a consciência é um elemento na percepção de um modo no qual a percepção por ouvintes não é evidentemente um elemento no testemunho. $\mathrm{O}$ testemunho não precisa ser recebido.

${ }^{14}$ De modo semelhante, uma crença básica, tal como uma derivada do testemunho, pode ser credível sem dependência positiva (por exemplo, inferencial), mas sem ser completamente independente de outras crenças, como por exemplo derrotadores potenciais. A distinção relevante (e frequentemente negligenciada) entre dependência epistêmica positiva e negativa é desenvolvida em meu "Foundationalism, Epistemic Dependence, and Defeasibility", Synthese, v. 55, p. 119-139, 1983. Esse artigo aplica a distinção à visão bem diferente de dependência epistêmica dada por Hilary Kornblith em "Beyond Foundationalism and the Coherence Theory", The Journal of Philosophy, v.8o, p. 597-611,1977.
} 
Uma vez que crenças testemunhais não precisam ser inferenciais e, assim, não precisam estar fundamentadas na crença de que o declarante é sincero (ou mesmo na crença de que alguém está falando com você), parece estranho que o testemunho não seja uma fonte básica de crença. $\mathrm{O}$ estranhamento pode se originar do fracasso em se compreender que a percepção pode ser uma exigência básica para a formação de crença baseada no testemunho mesmo que a crença perceptual não seja uma exigência para tal. Na verdade, para formar uma crença, baseada no testemunho de que o palestrante perdeu a calma, talvez eu precise estar disposto a crer que alguém me disse que isso aconteceu. Mas parece ser assim apenas porque preciso perceber isso sendo dito, não porque tenho de formar a crença de (ou de alguma forma crer) que isto foi dito, do mesmo modo que a percepção de uma sentença em um editorial convincente pode produzir crença no que a sentença diz, sem que se forme a crença de que a sentença diz isso. É minha percepção do que é dito, tipicamente eu ouvir ou ler, que é necessária para a formação de uma crença testemunhal sobre a proposição afirmada. Entender e crer no testemunho de que $p$, quando ouvimos o testemunho de que $p$, pode requerer que pressuponhamos, em algum sentido, que o declarante disse que $p$ - de modo que se (por exemplo) descremos que o declarante disse que $p$, não iremos crer que $p$ a partir do testemunho. Além disso, não é preciso negar que o cérebro - ou talvez a mente em um nível subconsciente - faça algum tipo de processamento de informação, talvez complexo, sem acarretar formação de crença. Mas duvido que crer que $p$ com base no testemunho exija crer que o declarante tenha dito que $p$, do mesmo modo que entender uma sentença que diz que $p$ não exige crer que a sentença diz que $p \cdot{ }^{15}$ Certamente a aquisição de crenças testemunhais não exige que a mente mantenha livros semânticos duplos.

O ponto positivo principal aqui é o de que o testemunho pode ser uma fonte de crença básica, no sentido mínimo de crenças não baseadas em outras crenças (em oposição ao sentido problemático de crenças com certo status epistêmico privilegiado). Esse tipo de crença pode também ser um caso de conhecimento básico, se satisfizer as condições para o

\footnotetext{
${ }^{15} \mathrm{E}$, com certeza, nem se requer isso. A qualquer um que queira atribuir uma crença aqui, eu sugeriria que as razões para fazê-lo podem ser adequadamente acomodadas sustentando que existe uma disposição para crer nisso (poderíamos chamá-la de crença implícita ou pressuposicional se tivermos em mente seu caráter especial). Meu “Dispositional Beliefs and Dispositions to Believe”, Nous, v. 28, n. 4, p. 419-134, 1994, defende essa sugestão.
} 
conhecimento não-inferencial (portanto, de não ser baseado em premissas), ${ }^{16}$ podendo, certamente, ser básico para uma pessoa, no sentido cotidiano de ser central na vida dela. Um ponto epistêmico importante, que o caso do testemunho ressalta, é o de que uma crença básica - grosso modo, básica na ordem das crenças de uma pessoa - não precisa vir de uma fonte básica de crença - grosso modo, que é básica na ordem das fontes cognitivas. Uma crença baseada no testemunho não precisa ser derivada de outras crenças, mesmo que sua formação dependa de uma fonte não-testemunhal de crenças - a percepção.

\section{A Epistemologia do Testemunho}

À luz do que emergiu quanto ao modo como o testemunho produz crenças, estamos em uma boa posição para perguntar como o testemunho produz conhecimento e justificação, e se ele porventura produz conhecimento ou justificação básicos do modo como a percepção e a reflexão, por exemplo, aparentemente o fazem. O caso de conhecimento é, em alguns aspectos, mais fácil de lidar do que o da justificação. Consideremos primeiramente o conhecimento.

Se de fato não sei que o palestrante perdeu a calma, você não pode vir a saber isso com base na minha afirmação. ${ }^{17}$ Isso é óbvio se estou enganado e ele não perdeu a calma. Mas, suponha que eu tenha um palpite feliz. Nesse caso, lhe passo uma informação que estimo estar correta, mas você também está correto por acaso, e também não sabe que ele perdeu a calma. É um acaso feliz eu ter acertado, e é mais do que um acaso feliz que você tenha acertado, uma vez que no seu caso existem, em acréscimo à

\footnotetext{
${ }^{16}$ A noção relevante de conhecimento básico não é uma noção forte; por exemplo, ela não está restrita ao conteúdo e é relativizada ao tempo, de modo que o que é básico para uma pessoa em um dado momento pode ser fundamentado em premissas em outro, e isso permite derrota por contraevidência, de modo que mesmo conhecimento básico pode ser removido. ${ }^{17}$ Você pode vir a sabê-lo a partir de alguma coisa sobre meu testemunho: talvez eu fale de modo nervoso, e você
sabe que o nervosismo revela que estou abalado pela explosão de humor, que eu já meio que esqueci e declaro de
modo conjectural. Esse seria um caso de crença simplesmente causada pelo testemunho, mas não baseada nele. Uma
condição para que uma crença seja baseada no testemunho é a de que aquele que crê sustente a proposição porque
ela foi afirmada, e não, por exemplo, devido ao modo como ela foi afirmada. Cf. Sosa, op. cit., p. 216-17. Este ponto
pode ser aplicado a um caso intermediário, no qual uma pessoa sabe que um falante sistematicamente distorce certa
questão, por exemplo exagerando suas realizações. Então, como um acompanhante lendo num tom e tocando em
outro, pode-se corrigir o erro. Isso pode produzir não apenas conhecimento baseado em algo sobre o testemunho,
mas conhecimento derivado semanticamente do testemunho. Outros casos, nos quais de algum modo o testemunho
produz conhecimento não estritamente baseado nele no sentido padrão, podem ser imaginados a partir desses
exemplos, mas tenho de deixá-los de lado aqui.
} 
eventualidade de eu ter me enganado, outros riscos a escapar: de que eu tenha distorcido a verdade, de que você tenha me ouvido mal, de que você tenha adicionado um detalhe falso ao meu testemunho, e assim por diante. Imagine, por outro lado, que não seja um palpite meu, mas que eu tenha incautamente aceitado a proposição de que o palestrante perdeu a calma, proferida por outra pessoa que eu sei que mente com frequência sobre os outros. Novamente, não tenho conhecimento de que ele perdeu a calma, mesmo que dessa vez a proposição seja verdadeira e, mais uma vez, outras pessoas não podem saber isso com base em meu testemunho, que agora está mal fundamentado de outro modo. O que não tenho, não posso dar.

Justificação é diferente: posso ser credível mesmo se não estou justificado em crer que o palestrante perdeu a calma, de modo que você pode vir a estar justificado em crer nisso com base na minha afirmação. Considere as duas facetas da credibilidade testemunhal: a dimensão da sinceridade, que diz respeito à honestidade do declarante, e a dimensão da competência, que diz respeito ao fato de o declarante ter conhecimento ou experiência suficientes para tornar pelo menos provável que, se o declarante forma uma crença de que $p$, então $p$ é verdadeira. Evidentemente, você pode justificadamente me considerar como tendo credibilidade quanto à questão de o palestrante ter perdido a calma, caso você tenha uma boa razão para crer que sou honesto, possuo acuidade e memória normais, e fui razoavelmente atento na ocasião.

Esse caso mostra, então, que enquanto o meu testemunho não pode dar a você conhecimento de que $p$, fundamentado no testemunho, sem que eu saiba que $p$, ele pode lhe dar justificação fundamentada no testemunho para crer que $p$ sem que eu tenha esta justificação - ou qualquer tipo de justificação - para crer que $p$. Esse ponto difere sutilmente da alegação que pode parecer equivalente: a de que eu não posso (por testemunho) lhe conceder conhecimento de que $p$, sem que eu saiba que $p$, e ainda assim eu posso (por testemunho) lhe conceder justificação para crer que $p$, sem ter qualquer justificação para crer que $p$. Essa alegação é, na melhor das hipóteses, enganadora. No caso do meu testemunho falso, mas credível, que fornece justificação para o que eu afirmo, o ponto principal não é o de que eu lhe forneço justificação para crer no que eu digo - que o palestrante perdeu a calma - sem ter essa justificação. É o modo como eu afirmo a proposição, juntamente com a justificação prévia que você possui sobre mim e sobre as circunstâncias 
que lhe proporciona esta justificação, independentemente de se eu a tenho ou não. Esse modo de conceder justificação não é o mesmo modo no qual o conhecimento é concedido. O conhecimento baseado no testemunho é recebido por transmissão, e assim depende de o declarante saber que $p$. É natural dizer que, no primeiro caso, você obteria conhecimento por meio do meu testemunho, enquanto que no segundo caso, você obteria justificação a partir do meu testemunho, mas não por meio dele.

$\mathrm{O}$ testemunho de que $p$ pode transmitir o conhecimento do declarante de que $p$ e pode produzir no ouvinte uma justificação para crer que $p$, mas não pode por si só transmitir a justificação que o declarante tem para crer que $p$. O declarante não precisa nem mesmo ter tal justificação. Este contraste ajuda a explicar a assimetria original: se eu não sei que $p$, meu testemunho de que $p$ não pode lhe transmitir conhecimento de que $p$ com base no testemunho; mas mesmo se não estou justificado em crer que $p$, meu testemunho pode lhe dar justificação com base em testemunho para crer que $p$, ao fornecer-lhe os materiais essenciais para que você esteja justificado em crer que $p .^{18}$

O contraste, entre como o testemunho produz conhecimento e como ele produz justificação naquele que o recebe, se assemelha a um contraste aplicável à memória. Da mesma maneira como não podemos saber que $p$ a partir da memória a menos que tenhamos vindo a saber que $p$ de algum outro modo, digamos através da percepção, também não podemos saber que $p$ com base no testemunho a menos que o declarante (ou alguém de quem o declarante veio a saber que $p$ ) tenha vindo a saber que $p$ (pelo menos parcialmente) de algum outro modo. Todavia, podemos nos tornar justificados em crer que $p$ através de impressões da memória, quer $p$ seja verdadeiro ou conhecido, ${ }^{19}$ e podemos nos tornar justificados em crer que $p$ com base no testemunho, quer o declarante tenha ou não

\footnotetext{
${ }^{18} \mathrm{O}$ qualificador 'baseado testemunhalmente' é crucial: suponha que eu declare, com voz de barítono, que eu tenho uma voz de barítono, mas eu não sei disso porque creio falsamente ter uma voz de tenor. Então você pode vir a saber, a partir de meu testemunho, mas não com base nele (de seu conteúdo), a proposição por mim afirmada. $\mathrm{O}$ mesmo ponto vale para a justificação em lugar do conhecimento. Pode-se também dizer que você veio a saber por meio do meu testemunho em sentido fraco de 'por meio de', que não implica que o conteúdo do que eu afirmo seja crucial. Além disso, o conteúdo, mas não o fato de eu declará-lo, pode ser crucial: se eu apresento um argumento, o qual você sabe que eu mal compreendo, você pode vir a ter conhecimento de sua conclusão, não devido ao fato de eu a afirmar, ou devido às premissas, mas com base em sua compreensão, à luz de conhecimento prévio, de que elas são verdadeiras e acarretam a conclusão. Isto seria conhecimento baseado no conteúdo do testemunho, mas não conhecimento baseado testemunhalmente.
}

${ }^{19}$ Desenvolvo e defendo este contraste em "Memorial Justification", Philosophical Topics, v. 23, p. 31-45, 1996. 
crença verdadeira ou conhecimento de que $p$, e mesmo que ele tenha ou não justificação para crer que $p$. Além disso, para o conhecimento baseado no testemunho, do mesmo modo que para o conhecimento com base na memória, aparentemente deve haver pelo menos uma cadeia epistemicamente válida ligando a crença que constitui o conhecimento a uma outra fonte do conhecimento, como a percepção, por exemplo. Mas para a justificação baseada no testemunho, como para a justificação baseada na memória, o que parece ser essencial é a presente situação epistêmica do sujeito da memória, ou daquele que recebe o testemunho, isto é, os conteúdos de consciência aparentemente memorial e o conteúdo e justificação de crenças prévias. A memória e o testemunho, podem ambos (de maneiras diferentes) gerar justificação, mas não são geradores de conhecimento: caracteristicamente, a primeira é preservativa e o último é transmissor. ${ }^{20}$

Existe outro modo no qual a justificação e o conhecimento aparentemente diferem em sua relação com o testemunho. Suponhamos que $e u$ estou justificado em crer que $p$, mas você não tem nenhuma justificação própria para crer que $p$ ou para me considerar credível a respeito da questão. Para variar o exemplo da conferência, imagine que de passagem, sem oferecer nenhuma evidência, eu diga que três palestrantes perderam a calma, e que as informações antecedentes de que você dispõe não infirmem nem apoiem essa alegação ou minha credibilidade no assunto. Aqui a justificação depende de você e não de mim: minha suposta contribuição para a sua justificação em crer que $p$ é derrotada porque você não tem justificação para pensar que meu testemunho é credível ou para crer que $p$ com base em outra coisa. Receber justificação requer às vezes que já se tenha justificação em alguma medida, como [ter justificação] para crer na credibilidade do declarante, ou para crer que $p$, ou para ambos. (A justificação pode também ser global caso a pessoa esteja justificada em crer, na ausência de fundamentos específicos para pensar o contrário, que um testemunho sério tende a ser verdadeiro.). O conhecimento parece ser um pouco diferente quanto a este ponto: para

\footnotetext{
${ }^{20}$ Deixo em aberto se conhecimento transmitido por testemunho pode ser tão bem fundado quanto o do declarante (apesar de eu estar inclinado a duvidar de que possa). Em contraste, no que concerne o conhecimento, "uma cadeia testemunhal não é mais forte do que seu elo mais fraco”, como Plantinga coloca (op. cit., p. 84). Ele está se referindo ao aval epistêmico, ou o que, grosso modo, torna a crença verdadeira um caso de conhecimento, e se o ponto vale também lá, então a justificação difere do aval epistêmico a este respeito, do mesmo modo como difere do conhecimento.
} 
saber algo devido à minha afirmação [de que tal é o caso] quando expresso meu próprio conhecimento, você não precisa saber que sou credível: é certamente suficiente que você tenha alguma razão para crer e nenhuma razão para duvidar que sou credível. Parece-me ser suficiente que você pressuponha isso e não tenha nenhuma razão para duvidar disso. Certamente você pode saber que são nove horas baseando-se em meu conhecimento disso, e no fato de eu dizer isso a você, mesmo se você simplesmente pensa que sou uma pessoa que parece normal, com um relógio de aparência normal e me considera credível. ${ }^{21}$ De fato, por que você precisaria satisfazer qualquer condição além de uma condição negativa: não ter qualquer razão para duvidar da minha credibilidade? Estamos falando de um caso no qual sei que são nove horas, afirmo isso a partir de meu conhecimento, e em consequência produzo sua crença (verdadeira) de que são nove horas. Essas condições parecem normalmente suficientes para que você saiba que são nove horas.

Essa conclusão parece plausível independente de qualquer explicação específica de conhecimento, mas é especialmente plausível a partir de uma perspectiva externalista e confiabilista. ${ }^{22}$ A idéia, em parte, é a de que o testemunho pode ser uma evidência (semanticamente encaixada) que desempenha um papel intermediário em um processo confiável de produção de crença. Ele pode ter esse papel, quer a pessoa que recebe o testemunho forme ou não crenças em apoio à credibilidade do declarante, quer ela faça ou não inferências sobre a competência do declarante, ou sobre a probabilidade de $p$; ou tenha ou não outros fundamentos positivos que apoiem a credibilidade.

Claro que é difícil encontrar casos de conhecimento de que $p$ fundamentados em tal processo natural e confiável que não sejam acompanhados por esses ou outros fundamentos que produzem justificação para $p$. Mas consideremos o seguinte: recebo uma carta em agosto na qual, em um aparte, Gisele me diz que ela estará em um encontro em dezembro. Creio nela e (deixando o ceticismo de lado) posso agora saber que ela irá ao encontro. Em outubro recebo outra carta na

\footnotetext{
${ }^{21}$ Se é assim, isso pode mostrar algo mais: supondo-se que você não pode ter conhecimento de uma proposição com base em premissas das quais você também não tem conhecimento, esse caso mostraria que seu conhecimento testemunhal não é inferencial, uma vez que a suposta premissa de credibilidade não é conhecida.

${ }^{22}$ Por exemplo, do tipo que encontramos em Fred Dretske em Knowledge and the Flow of Information (Cambridge: MIT, 1981); Alvin I. Goldman em Epistemology and Cognition (Cambridge: Harvard University Press, 1986); e William P. Alston em Epistemic Justification (Ithaca: Cornell University Press, 1989), por exemplo, no cap. 7.
} 
qual ela não menciona o encontro. No final de novembro sou perguntado se ela irá ao encontro, e digo - de memória - que ela irá. Certamente meu testemunho pode permitir que meu ouvinte saiba que ela irá ao encontro, mesmo se eu não me lembrar como cheguei a pensar isso, por exemplo, porque eu posso me lembrar agora apenas da segunda carta. Ainda assim, lembro que ela irá ao encontro, o que presumivelmente implica que eu sei que ela irá ao encontro. Posso também ter bases indutivas para pensar que se me parece recordar algo assim [que ela irá ao encontro], então sei disso, mas duvido que alguém deva ter esse tipo de fundamento. Talvez, eu nem mesmo tenha algo em favor de minha crença que possa ser apropriadamente chamado de justificação, mas, ainda assim, (com base em minha memória excelente) posso saber a proposição em questão.

Uma objeção natural a esta concepção credível-exceto-indicadocontrariamente do testemunho como base para o conhecimento é a de que, em nosso exemplo, a evidência possuída pela pessoa é tão limitada que ela só poderia ter no máximo alguma razão para crer que Gisele irá ao encontro ou de que são nove horas. Mas será isso verdade? Reconhecidamente, que uma pessoa tem alguma razão para crer na [verdade da] proposição pode ser tudo o que ela pode mostrar a partir de sua evidência ou a partir do que ela se sente segura. Ainda assim, certamente eu de fato sei que são nove horas e que Gisele irá ao encontro, e se eu lhe digo, com sinceridade, que ela irá, você pode por isso saber que ela irá. Uma cadeia epistemicamente válida conecta a crença que você forma com o testemunho direto de Gisele. Isso parece valer mesmo quando você simplesmente não tem qualquer razão para duvidar de minha credibilidade. Uma teoria do por que isto ocorre é a de que (algum) testemunho pode servir como um tipo de substituto para nossa própria percepção, e algumas vezes podemos confiar na palavra de outros com tanta segurança quanto em nossos próprios sentidos. Se o testemunho nunca pode servir dessa maneira - se ele nunca é um intermediário social confiável entre aquele que recebe o testemunho e o mundo representado pelo testemunho - então em questões científicas, e mesmo nos casos em que nos apoiamos menos em outros do que nesse tipo de questões, sabemos muito menos do que comumente supomos.

Se esses pontos sobre o testemunho enquanto fonte de justificação e conhecimento são válidos, pelo menos dois princípios aplicáveis ao testemunho aparecem como plausíveis. No que respeita ao 
conhecimento, podemos dizer que, pelo menos normalmente, uma crença de que $p$ baseada no testemunho constitui, em consequência, conhecimento (isto é, conta como conhecimento baseado no testemunho), desde que o declarante saiba que $p$ e que o sujeito da crença não tenha razões para duvidar, seja de $p$, seja da credibilidade do declarante. Do ponto de vista do confiabilismo, uma maneira de colocar essa ideia principal é dizer que, normalmente, a fundamentação confiável de crenças verdadeiras é transmissível através do testemunho. ${ }^{23}$ Podemos dizer com relação à justificação que, pelo menos normalmente, uma crença baseada no testemunho é, em consequência disso, justificada (isto é, conta como justificada com base no testemunho) desde que o sujeito da crença tenha justificação total para tomar o declarante como credível no que respeita a proposição em questão. Ter tal justificação implica uma capacidade para inferir, por exemplo, sobre a confiabilidade do declarante, mas não implica fazer uma inferência efetiva, consciente ou inconsciente. De todo modo, o primeiro princípio sugere que o testemunho serve - ou pode servir - como um fundamento para o conhecimento de um modo externo; o segundo princípio sugere que ele serve como um fundamento para a justificação só se aquele que recebe o testemunho tem, inicialmente, justificação em alguma medida. ${ }^{24}$ (Suporte adicional para este contraste e suas implicações para o aprendizado de linguagem são explorados na seção IV.)

Quaisquer que sejam as condições exatas sob as quais o testemunho dá fundamento ao conhecimento e à justificação, até aqui não encontramos nenhuma razão para duvidar que, sob algumas condições, o testemunho pode produzir seja conhecimento seja crença justificada em quem forma crença ao receber o testemunho. Parece, contudo, que o testemunho não pode ser uma fonte básica de conhecimento, uma vez que

\footnotetext{
${ }^{23}$ A qualificação de normalidade é exigida, em parte, devido a problemas que não são peculiares ao testemunho, dizendo respeito ao que constitui conhecimento. Para uma indicação de quão difícil esses problemas podem ser para o testemunho e outras fontes potenciais de conhecimento, ver Fred Dretske, "A Cognitive Cul-de-Sac", Mind 91 (1982), p. 109-11, e a discussão de Coady sobre esse artigo, op. cit., 224-30. É preciso notar também que o que chamo de base para uma crença não inclui todas as condições necessárias para ela. Mas explicar esta distinção é uma tarefa importante da qual não posso me ocupar aqui.

${ }^{24}$ Esses princípios são formulados com cautela: eles permitem, por exemplo, que circunstâncias anormais possam produzir exceções; que uma crença testemunhal possa ser inferencial, que a justificação resultante não seja forte mas apenas "adequada" para crença razoável; que o sujeito tenha justificação para $p$, ou conhecimento de que $p$, a partir de outra fonte também, que a justificação daqueles que recebem o testemunho, em relação à credibilidade do declarante seja fraca (apesar de não derrotada); e que o conceito de justificação seja principalmente interno, ou principalmente externo. O princípio epistêmico pode ser ampliado através da especificação de que aquele que recebe o testemunho não tenha uma razão global para duvidar, mas deixo esta qualificação em aberto.
} 
uma pessoa não pode saber algo com base no testemunho a menos que o declarante também o saiba. O testemunho transmite conhecimento mas, enquanto tal, não gera conhecimento. Pode gerar conhecimento incidentalmente, como quando ao dizer em tom de surpresa que são quatro da manhã, forneço a um companheiro insone conhecimento de que estou acordado. Esse conhecimento não está fundamentado no testemunho, mas no simples ouvir o que é dito, e este tipo de conhecimento poderia facilmente ser transmitido por um sussurro.

O testemunho, do mesmo modo como a inferência, pode existir em cadeias indefinidamente longas. Um declarante pode saber que $p$ com base no testemunho de que $p$ de uma terceira pessoa, que pode saber que $p$ com base no testemunho de uma quarta pessoa, em vez de a partir de uma fonte geradora como a percepção. Quanto esta cadeia pode recuar? Existe, com certeza, algum limite para cada situação, ao contrário de um regresso infinito, e deve haver um limite, mesmo independente do tempo requerido para receber o testemunho, como podemos ver ao considerarmos outro ponto de vista segundo o qual o testemunho não é uma fonte básica de conhecimento. Certamente, se ninguém soubesse algo de modo não-testemunhal, ninguém poderia saber nada com base no testemunho. Isto não equivale dizer que tudo que é conhecido (mesmo em parte) de modo vinculado à base testemunhal deve ser também conhecido por alguém totalmente com outras bases. Considere um mapa desenhado de modo cooperativo por uma equipe: cada componente da equipe conhece em primeira mão alguma parte do território mapeado, mas nenhum deles conhece a forma total, exceto (largamente) por meio do testemunho dos outros. Assim, apesar de o conhecimento parecer depender em última instância de conhecimento não-testemunhal - por exemplo, conhecimento fundamentado na percepção ou na reflexão - nem tudo o que é conhecido testemunhalmente é também conhecido de modo não-testemunhal. Para que outros saibam alguma coisa através de minha afirmação, tenho de possuir eu mesmo este conhecimento, e meu conhecimento deve depender em última instância, pelo menos parcialmente, de conhecimento baseado de modo não-testemunhal, como o conhecimento baseado em ver que o relógio marca nove horas; mas, trabalhando em conjunto, podemos fornecer testemunho que leva 
R. Audi - O lugar do testemunho na estrutura do conhecimento e da justificação | 583

conhecimento para além do que é discernível a partir de qualquer subconjunto próprio de nossas outras fontes. ${ }^{25}$

Podemos tentar reforçar a concepção segundo a qual o conhecimento testemunhal depende de outro conhecimento, da maneira que segue. Mesmo se alguém afirma que $p$ na minha presença, eu teria de perceber isso e saber alguma outra proposição de apoio, por exemplo, que alguém credível disse que $p$. No entanto, uma vez que o ponto é colocado desse modo, ele, evidentemente, não pode ficar sem qualificação. O tipo de percepção requerido não acarreta formar uma crença dessa espécie, talvez nem mesmo uma crença (parcialmente) perceptual específica de que alguém disse que $p$. Desse modo, o caso mostra, apenas que o testemunho é operacionalmente dependente da percepção, não que ele é inferencialmente dependente da crença perceptual. O testemunho requer material perceptual bruto, mas não requer que se creia em quaisquer premissas sobre esses materiais. ${ }^{26}$

Se o conhecimento e a justificação baseados no testemunho não dependem de premissas que apoiem a crença fundamentada no testemunho - digamos premissas que confirmem a credibilidade do declarante - isso explica como tal crença pode ser básica. O testemunho, como fonte de conhecimento e justificação, não precisa ser básico relativamente a outras fontes de conhecimento e justificação para que crenças testemunhais sejam básicas na ordenação das crenças. Este ponto, no entanto, é diferente do ponto referido acima - de que o conhecimento do declarante, que é base do conhecimento do ouvinte, não pode ser, em última instância, fundamentado inteiramente no testemunho. Ademais, o conhecimento que é direta e inteiramente baseado no testemunho para aquele que recebe o testemunho, não pode em última instância ser baseado inteiramente no testemunho para o declarante: o primeiro não teria nenhum "direito" de transferir o testemunho ao segundo, do mesmo modo

\footnotetext{
${ }^{25} \mathrm{O}$ caso do mapa é de Plantinga, op. cit. p. 87. Ele difere do caso de Hardwig, op. cit., em que, enquanto o que qualquer um dos cartógrafos sabe (amplamente) com base no testemunho é equivalente a uma conjunção de itens conhecidos não-testemunhalmente por um ou mais cartógrafos, o caso da cooperação científica é mais complicado. Alguns coautores podem carecer de conhecimento não-testemunhal não apenas de uma conclusão importante, mas também tanto de seus fundamentos como dos princípios de raciocínio pelos quais se pode ver que esses fundamentos dão apoio à conclusão. Os princípios especiais que se aplicam a esses e outros casos de fundamentos mistos são epistemologicamente importantes, mas não posso me ocupar deles aqui.

${ }^{26}$ Quanto a este ponto discordo de Fricker, que sustenta que o receptor deve crer perceptualmente "que o falante fez uma asserção com um conteúdo particular ... capaz de ser conhecimento." Ver "The Epistemology of Testimony”, citada na nota 1.
} 
como eu não teria nenhum direito a dar a alguém algo que eu tivesse simplesmente tomado emprestado de outro, o qual tenha simplesmente tomado emprestado de um terceiro, e prosseguindo assim ao infinito.

Um ponto importante se refere a crenças com base no testemunho poderem ser não-inferenciais e, desse modo, independentes de premissas. Contudo, a dependência operacional do testemunho tem tanto importância epistemológica como conceitual, pois se uma pessoa não tiver fundamentos perceptuais para o conhecimento ou pelo menos para a crença justificada de que alguém afirmou que $p$, essa pessoa não poderia saber que $p$ com base no testemunho. Essa é uma dependência epistêmica que não tem paralelo no caso da percepção. ${ }^{27}$ Isso mostra que, mesmo se o conhecimento baseado no testemunho não precisa depender inferencialmente de se ter conhecimento fundamentado de outro modo, ele é dependente epistemicamente de se ter fundamentos de outro modo, fundamentos para o conhecimento neste outro modo. Em consequência, o conhecimento testemunhal depende da - e neste sentido pressupõe a disponibilidade, ou se poderia dizer da cooperação potencial, de outra fonte de conhecimento, mesmo que tal conhecimento não requeira a operação efetiva dessa fonte na produção de crenças nas premissas que essa fonte está apta a fornecer.

O caso da justificação é similar neste aspecto. Não posso adquirir justificação para crer em algo com base no testemunho a menos que eu tenha algum grau de justificação para crer que o declarante é credível, bem como tenha algum grau de justificação para certas outras proposições, como a de que eu ouvi corretamente o testemunho. Esta justificação não pode vir inteiramente do testemunho. Jane pode me tranquilizar sobre Bert. Mas, e se não tenho justificação para considerar Jane confiável? Outras bases para a justificação, tal como a percepção ou a memória, devem, no mínimo tacitamente, cooperar. Mas sua cooperação pode ser justificacional sem ser inferencial: elas não precisam produzir, em mim, crenças em premissas a partir das quais eu infiro que o declarante é confiável; elas simplesmente me dão uma justificação para usar tais premissas se eu precisar delas.

\footnotetext{
${ }^{27}$ Concedo que a justificação perceptual depende de um modo negativo de outras fontes (incluindo fontes perceptuais), uma vez que ela pode ser derrotada devido a seus resultados conflitantes, mas aqui a dependência é positiva.
} 
Pode ser de algum auxílio descrever uma de minhas conclusões gerais - a de que o testemunho não é uma fonte básica de conhecimento ou justificação - como reflexo do contraste entre um modelo central em psicologia do testemunho e um dos aspectos principais da epistemologia do testemunho. Frequentemente, quando ouvimos pessoas declarar as mais variadas coisas, nós simplesmente cremos nessas coisas de modo não-inferencial e mesmo sem reservas. Mas esse processo psicológico natural produz conhecimento e justificação apenas quando certas condições epistêmicas são satisfeitas: é preciso existir fundamentos para o conhecimento e a justificação, oriundos de outra fonte, mesmo que não seja preciso existir conhecimento ou crença justificada sobre as proposições avalizadas por estes fundamentos. No caso do conhecimento testemunhal, é preciso existir conhecimento, ainda que não necessariamente justificação, por parte do declarante, enquanto que no caso da justificação baseada no testemunho é preciso haver justificação, ainda que não conhecimento, por parte do receptor. A primeira exigência diz respeito à situação epistêmica do declarante relativamente à proposição afirmada; a segunda, diz respeito à situação epistêmica daquele que recebe o testemunho, relativamente ao declarante, ou relativamente à proposição, ou a ambos. ${ }^{28}$ Em conjunto, as exigências indicam como, psicologicamente falando, apesar de o testemunho ser uma fonte de crenças básicas, ele não é, epistemicamente falando, uma fonte básica de conhecimento e justificação.

\section{A centralidade conceitual e de desenvolvimento do testemunho}

A dependência epistêmica do testemunho em relação a outras fontes de crença deve se harmonizar com o fato evidente de que crianças pequenas aprendem - e, portanto, adquirem conhecimento rudimentar a partir do que os outros lhes dizem, mesmo antes que se possa dizer, com propriedade, que elas têm fundamentos para o conhecimento ou para a justificação no que concerne a credibilidade do declarante. Consideremos o aprendizado do nome de cores. Depois de algum tempo, a criança aprendeu, por exemplo, que o sofá é vermelho. Mas a criança pequena não

\footnotetext{
${ }^{28}$ A epistemologia do testemunho sugerida aqui pode ser mais restritiva do que a de Reid. Para uma interpretação e defesa da concepção, aparentemente reidiana, de que crenças baseadas no testemunho não precisam depender para sua justificação de outras fontes, ver Webb, op. cit.
} 
tem o conceito de credibilidade, nem tampouco outras noções importantes para a aquisição de justificação a partir do testemunho, e sua experiência é inicialmente insuficiente para que ela esteja justificada em crer que quem a ensina é credível. Na concepção desenvolvida aqui, este ponto é inteiramente compatível com a aquisição de conhecimento por parte da criança.

A primeira coisa a observar ao explicar esta compatibilidade é que existem, pelo menos, duas maneiras de se aprender a partir do testemunho: uma pessoa pode aprender (no sentido de vir a saber) o conteúdo afirmado, e ela pode aprender algo que é demonstrado pelo próprio testemunho. O primeiro caso é aprender que, isto é, que algo é de determinado modo; o segundo é aprender de ou sobre algo (e pode se estender a aprender como). Uma criança pequena aprendendo as cores básicas não está, primariamente, aprendendo que (por exemplo) o sofá é vermelho, mas, sobretudo, ela está se tornando consciente da vermelhidão como cor do sofá. Ao introduzir 'vermelho', os pais afirmam apenas de modo incidental a proposição de que o sofá é vermelho, e a criança pode aprender a lição principal sem conceitualizar o sofá enquanto tal. A questão é associar 'vermelho' a uma instância daquilo que esse conceito representa, de modo a ensinar a criança esta palavra (ou, por exemplo, o que a cor vermelha é). No primeiro caso - o testemunho proposicional pode resultar em conhecimento proposicional; teríamos então aprendizado proposicional. A introdução de vocabulário pelos pais testemunho ostensivo - pode resultar em aprendizado conceitual.

É importante ver que, aparentemente, as condições de sucesso para a função introdutória da linguagem requerem que a maior parte das afirmações sejam, pelo menos aproximadamente, verdadeiras. Normalmente, uma criança não pode aprender o que é 'vermelho' a menos que, ao ensinar português à criança, a maior parte dos objetos aos quais 'vermelho' é aplicado sejam vermelhos. ${ }^{29}$ É claro que isto não mostra que a maioria dos testemunhos é verdadeira, mas implica que se a comunicação está ocorrendo quando o testemunho é dado, então uma pessoa pode razoavelmente assumir que, tanto o declarante como o receptor do testemunho se beneficiaram a uma certa altura de um

\footnotetext{
29 De modo estrito, precisam apenas parecer vermelhos, como quando objetos brancos são iluminados por luz vermelha. Supostamente, pode-se ensinar 'vermelho' produzindo apenas alucinações dessa cor.
} 
background no qual uma proporção substancial de certo tipo de afirmações era verdadeira. Este ponto pode, por sua vez, fornecer algum suporte para se tomar o testemunho como sendo normalmente credível, pelo menos quando o declarante está se comunicando com aquele que recebe o testemunho. ${ }^{30}$

Geralmente, crença e conhecimento são adquiridos na época em que os conceitos estão sendo inicialmente entendidos. Não é autoevidente, no entanto, que condições suficientes para o aprendizado conceitual impliquem o aprendizado proposicional. ${ }^{31} \mathrm{O}$ testemunho produz facilmente ambos em conjunto, mas se ele não pode produzir o primeiro sem o último, aparentemente ele pode produzir o último sem o primeiro. No entanto, é difícil dizer quando uma criança começa a formar crenças em vez de imitar os mais velhos, dizendo coisas através das quais os adultos expressam crenças. Suponhamos ambos, que muito cedo na vida e que muitas das primeiras crenças formadas - ou mais provavelmente, grupos iniciais de crenças - se baseiam no que os adultos dizem à criança que é o caso. Será que isto deve colocar um problema para a epistemologia do testemunho sugerida aqui? Novamente, considerar conhecimento e justificação separadamente será de alguma ajuda.

Falamos que bebês e crianças, muito cedo em suas vidas, sabem algumas coisas. Alguém poderia objetar que esse tipo de conversa é simplesmente projetivo: nós saberíamos se estivéssemos na situação da criança e nos comportássemos do modo relevante, e assim dizemos que a criança sabe. Essa linha é defensável mas suponhamos, para efeitos de argumentação, que na época em que as crianças começam a falar elas de fato sabem certas coisas. Podemos certamente falar de seu aprendizado de que o leite se derrama quando é entornado, que o forno é quente, e

\footnotetext{
${ }^{30} \mathrm{O}$ ponto pode ser conectado com alguns argumentos tais como os que Donald Davidson oferece para mostrar que a maioria de nossas crenças devem ser verdadeiras, mas não implica esta conclusão mais forte. Para discussão dessa e outras hipóteses davidsonianas, ver Coady, op. cit., em especial o cap. 9. Confronte com Fricker: "É plausível que 'Não faça nenhuma atribuição espontânea de insinceridade' e o princípio paralelo para crenças falsas estão entre as NIs [normas de interpretação]. Mas isso não assegura que a melhor descrição interpretativa de um indivíduo o mostrará como sendo sobretudo sincero ou como tendo principalmente crenças verdadeiras ... é efetivamente um fato empírico contingente, não garantido por nenhuma norma de constituição de conceito ...que, em determinada comunidade linguística, aproximadamente todos os proferimentos sinceros são desse modo, e que os falantes na comunidade quase sempre têm crenças verdadeiras ... [apesar de que] existe uma ligação vaga e inferior com a possível incidência de insinceridade e de crença falsa. (“Against Gullibility”, p. 152-3).

${ }^{31}$ É difícil ver como se poderia, através do testemunho, produzir o aprendizado conceitual sem produzir alguma crença. Uma criança poderia se familiarizar com o que é a vermelhidão em conexão com o fato de lhe dizerem que o sofá é vermelho, e ainda assim não adquirir nenhuma crença, por exemplo, crer (de re) de que o sofá é vermelho?
} 
assim por diante - e aprender (em geral) implica conhecimento. Mais ou menos na mesma época, as crianças começam a aprender coisas com base no testemunho, por exemplo, que o vapor da água é quente.

Se, como parece ser uma suposição razoável, obter conhecimento testemunhal normalmente requer apenas que não se tenha razões para duvidar da credibilidade do declarante, então a concepção proposta acima não encontra nenhuma dificuldade. Mesmo que uma criança muito pequena talvez possa não ter qualquer razão para duvidar, a criança um pouco maior certamente não tem nenhuma; nem é preciso aqui existir qualquer razão para duvidar, uma vez que muitos testemunhos são altamente credíveis. Uma exigência mais forte pode parecer apropriada: a de que a criança tenha (possivelmente de um modo pré-conceitual) algum fundamento para tomar o falante como credível, por exemplo, experiências repetidamente confirmando o que o falante diz. Talvez se possa esboçar, para tal fundamento correlativo, condições suficientemente elementares para se ajustar ao caráter rudimentar do conhecimento infantil. No entanto, duvido que conhecimento baseado no testemunho exija tal fundamento.

Pode ser mais difícil lidar com o caso de crianças pequenas relativamente à justificação. Mas cabe observar que não usamos o vocabulário da justificação, em comparação com o de conhecimento, para criaturas tão não-desenvolvidas conceitualmente. Para que uma criança esteja justificada em crer que o sofá é vermelho, ela teria de ser capaz não apenas de ter um fundamento para crer nisso mas, de modo correspondente, de não ter tal fundamento e crer nisso de qualquer modo, estando assim não justificada. Supostamente, na época em que podemos falar com propriedade de crianças desse modo duplo (o que talvez deva se dar logo depois de conseguirem falar), elas efetivamente têm uma compreensão do histórico de adultos dando-lhes informações que são confirmadas pelas experiências delas. Se os pais dizem que está frio lá fora, é porque está, e assim por diante. É claro que as crianças não usam a noção de credibilidade, mas elas podem entender conceitos relacionados, tais como aqueles necessários para a compreensão de que a mamãe está certa sobre coisas e que o irmãozinho deve ser corrigido. Quanto mais natural e menos figurativo parecer falar de crianças crescendo e adquirindo justificação com base no testemunho, tanto mais fácil será encontrar algum modo elementar segundo o qual elas podem satisfazer as condições 
epistêmicas e justificacionais estabelecidas acima, tais como a de fazer discriminações que lhes permitam avaliar o que lhes é dito e avaliar os históricos dos testemunhos daqueles que estão à sua volta.

Nada do que foi dito pretende estabelecer quando o conhecimento e a justificação entram em cena no desenvolvimento humano, seja por meio do testemunho ou de fontes mais básicas. Essas questões são prerrogativas dos psicólogos; uma explicação filosófica da epistemologia do testemunho só precisa deixar espaço para respostas plausíveis. A teoria descrita aqui sugere que o conhecimento surge antes da justificação. $\mathrm{O}$ conhecimento baseado no testemunho parece ser parte da fundação cognitiva a partir da qual as crianças adquirem a evidência de que precisam para alcançar justificação para aceitar o testemunho. Talvez este ponto seja parcialmente explicado pela descrição do aprendizado conceitual que esbocei ao descrever o testemunho ostensivo. Em poucas palavras, a ideia é a seguinte: na ordem de desenvolvimento natural das coisas, o conteúdo vai do exterior para dentro, enquanto a justificação vai do interior para fora. Sem a conceitualização, que surge a partir da introdução testemunhal de conteúdo, não haveria nenhum fundamento interno rico o suficiente para promover a justificação. Particularmente em crianças, o conhecimento baseado no testemunho surge inextricavelmente ligado à conceitualização. Este êxito epistêmico externo de alguns testemunhos é uma precondição para as evidências internas que dão justificação à criança para aceitar outro testemunho.

\section{A indispensabilidade epistêmica do testemunho}

A concepção de que o testemunho não é uma fonte básica de justificação ou de conhecimento é facilmente mal compreendida: não implica que o testemunho seja menos importante na vida humana normal do que uma fonte básica. Uma fonte de conhecimento e justificação pode ser indispensável na vida mesmo que ela não seja básica. Pode ser que nenhum ser humano normal [jamais] viesse a saber nada se não fosse através de testemunho. ${ }^{32}$ Suponhamos que não haja conhecimento inato

\footnotetext{
${ }^{32}$ Uma razão para que este ponto se restrinja aos seres humanos normais é a de que parece possível para um ser humano ser criado artificialmente como um adulto completamente desenvolvido e, nesse caso o conhecimento de muitas proposições abstratas, e talvez de outros tipos como o conhecimento do ambiente externo perceptível, pode ocorrer antes de que o testemunho seja recebido.
} 
(apesar de eu querer deixar isso em aberto), e que ninguém soubesse coisa alguma antes do aprendizado de uma língua. Então, a menos que se pudesse adquirir competência linguística sem a ajuda de outras pessoas, elas seriam essenciais para que se soubesse qualquer coisa. Ademais, se tentássemos imaginar o que restaria se fossem eliminados todo o conhecimento e todas crenças que já adquirimos com base no testemunho, parece que não conseguiríamos realizar essa seleção. Até mesmo dar início à tarefa de colocar de lado o que sabemos no modo indicado sugere que seríamos, na melhor das hipóteses, empurrados novamente para um estágio primitivo de aprendizado.

Esses e outros pontos levantados acima podem ajudar a avaliar a influente concepção de Hume, de que o testemunho só é capaz de fundamentar conhecimento com base em um tipo de legitimação a partir de outras fontes. A concepção pode ser aplicada à prática generalizada de se apoiar no testemunho, ao testemunho de um grupo particular ou de um indivíduo, e a uma afirmação individual. No primeiro caso, que é global, uma questão importante é se podemos conceber uma noção de justificação geral que considere o testemunho humano como sendo confiável. No segundo caso, que é local, (algumas instâncias do qual são de mais ampla classificação do que outras), algumas crenças baseadas no testemunho podem estar pressupostas na justificação de uma ou mais crenças. $\mathrm{O}$ mesmo se dá no terceiro caso, que é focal, no qual uma única crença está em questão. Hume é um bom ponto de partida para a reflexão sobre qualquer um desses problemas de justificação. Minha preocupação aqui é principalmente com o status de crenças individuais, mas o que se segue também é pertinente a problemas mais amplos de justificação. Para Hume, toda "segurança" fundada no testemunho "não deriva de outro princípio que não seja a nossa observação da veracidade do testemunho humano e da conformidade usual dos fatos aos relatos das testemunhas". ${ }^{33}$ Deixando de lado a questão de se esta alegação implica que crenças baseadas no testemunho devem ser inferenciais, será verdade que, para cada proposição na qual uma pessoa crê justificadamente com base no testemunho, ela deve ter uma justificação oriunda de outras fontes?

${ }^{33}$ An Enquiry Concerning Human Understanding, L. A. Selby-Bigge, ed. (Oxford: Oxford University Press, 1902), seção 88 . 
Já insisti em uma resposta negativa à questão correlata quanto ao conhecimento, mas a justificação pode diferir a esse respeito. Uma vez que essas fontes não-testemunhais incluiriam crenças memoriais justificadas, elas poderiam contribuir com proposições originariamente baseadas em um testemunho que é independente de testemunho que precise de apoio. Muito do que é armazenado em nossas memórias são crenças que formamos a partir do testemunho. Supondo que o que foi aprendido por testemunho e é preservado pela memória pode justificar a crença em uma proposição que alguém afirma, pode ser que muitas pessoas alcancem um ponto no qual, para tudo o que elas creem justificadamente com base no testemunho, elas têm mesmo algum grau de justificação fundada independentemente do testemunho em questão. Por exemplo, muitas das minhas crenças sobre as condições nas quais o testemunho é credível são preservadas em minha memória, portanto, mesmo que eu não tenha nenhuma evidência para $p$, posso, nas circunstâncias de uma afirmação, estar justificado em pensar que o proferimento do declarante é uma razão para crer que $p$. Algumas dessas crenças memoriais justificadas, no entanto, dependem para sua justificação de eu estar previamente justificado em crer em algo com base no testemunho, como quando aceito o testemunho de alguém para verificar o testemunho de outra pessoa. Pode existir, então, uma espécie de circularidade ao apelar para crenças justificadas com base na memória, originalmente justificadas com base no testemunho, como suporte para outro testemunho.

Pode ser alegado que, uma vez que a memória é uma fonte básica de justificação e uma vez que o próprio testemunho é uma fonte de justificação não-inferencial, pode não haver nenhuma circularidade viciosa. Acho que esta alegação é plausível, mas de modo algum ela é obviamente correta. ${ }^{34}$ Consideremos um programa de notícias que anuncia um terremoto na Indonésia. Com base na memória, tenho presente o histórico do programa e da situação geológica na Indonésia, e quão frequentemente erros desse tipo acontecem, etc. Tal justificação está longe de ser conclusiva, mas ela não precisa, aparentemente, ser inadequada devido a uma circularidade viciosa.

Será que se pode ir além do modesto projeto que acabamos de descrever, e modelar uma justificação global abrangendo todo o conjunto de crenças testemunhais (ou originalmente formadas com base no testemunho

\footnotetext{
${ }^{34}$ Para uma discussão proveitosa sobre como crenças testemunhais podem ser justificadas e sua semelhança neste respeito às crenças memoriais, ver Sosa op. cit., especialmente p. 218-22.
} 
e retidas pela memória)? Será que alguém poderia produzir esse tipo global de justificação para suas próprias crenças baseadas no testemunho? Suponhamos que alguém não aceite que algumas crenças testemunhais possam justificar outras crenças desse tipo e tente suspender o juízo sobre todas as suas crenças baseadas no testemunho (assumindo-se que tal suspensão massiva do juízo seja possível). Certamente este projeto amplo de justificação fracassaria. ${ }^{35}$ É duvidoso que possamos sempre evitar apoiar-nos no testemunho, pelo menos indiretamente, ao avaliar o testemunho. A compreensão de alguém sobre o histórico do declarante, por exemplo, depende tipicamente do que ele crê a partir do testemunho, como quando uma fonte de notícias serve para checar uma outra.

Parece não haver um procedimento geral, segundo o qual se possa produzir uma justificação global para a proposição de que todo o conjunto de nossas crenças testemunhais (ou mesmo a maior parte dele) é justificado. Mas não há necessidade de se tentar este projeto global, ou nem mesmo seu correlato local para um dado indivíduo, e a epistemologia do testemunho que esbocei implica no máximo, a este respeito, que crenças testemunhais que são justificadas, sejam individualmente justificáveis para o sujeito da crença em questão, pelo menos parcialmente, em termos das fontes de justificação "básicas" (ou outras preferidas), tais como a percepção e a reflexão. ${ }^{36}$ Para o conhecimento baseado no testemunho nem isto parece ser necessário. As condições nas quais o conhecimento é testemunhalmente transmitido parecem não depender da justificação da mesma maneira: apesar de o testemunho de que $p$, dado por alguém que sabe que $p$, poder ser derrotado por crenças justificadas e contrárias a $p$, normalmente, na ausência de tais crenças aquele que recebe o testemunho adquire conhecimento, mesmo sem ter justificação quanto à credibilidade do declarante. Se não fosse assim, seria no mínimo difícil explicar como crianças aprendem uma linguagem do modo como o fazem.

\footnotetext{
${ }^{35}$ Não seríamos certamente capazes de apelar para nenhum segmento significativo do conhecimento científico, pois ali somos fortemente dependentes do testemunho, escrito ou oral. Um caso plausível de que esta dependência é ainda maior do que parece é apresentado por Hardwig, op. cit.

${ }^{36}$ Para considerações em favor da possibilidade de justificação local e contrária à justificação global, ver os artigos citados por Fricker na nota 1, e em seu "Telling and Trusting: Reductionism and Anti-Reductionism in the Epistemology of Testimony, em C. A. J. Coady, Testimony: A Philosophical Study”, Mind, v.104, p. 393-411, 1995.
} 
R. Audi - O lugar do testemunho na estrutura do conhecimento e da justificação | 593

\section{Conclusão}

O testemunho é uma fonte de crenças disseminada e natural. Com certeza, muitas das crenças nele fundamentadas são justificadas ou constituem conhecimento. Elas podem até mesmo constituir conhecimento básico ou crença básica, ambos no sentido (moderado) de que elas não estão fundamentadas em premissas e no sentido em que elas desempenham um papel essencial na vida do sujeito da crença. Podemos, portanto, dizer que crenças baseadas no testemunho são psicológica, epistêmica e existencialmente básicas. Mas elas são epistemicamente básicas apenas no sentido em que não dependem inferencialmente de conhecimento ou de crença justificada de premissas anteriores. Elas são epistemicamente dependentes, de um modo que crenças perceptuais não o são, de que a pessoa tenha fundamentos para o conhecimento ou justificação, e são psicologicamente dependentes de a pessoa ter pelo menos algum fundamento não-proposicional - tal como ter ouvido alguém dizer - em outro modo experiencial e não-testemunhal. Mas esta dependência de fontes não torna o testemunho dependente de premissas. O testemunho é uma fonte geradora de crenças: ele produz novas crenças sem que nós simplesmente as derivemos inferencialmente a partir de crenças que já possuímos.

O testemunho não é (exceto incidentalmente) uma fonte geradora de conhecimento; ele não produz conhecimento novo independentemente de conhecimento que já temos. E se eu estou correto, ele é muito diferente enquanto fonte de conhecimento, o qual ele transmite, do que é enquanto fonte de justificação, a qual ele produz apenas em cooperação com a justificação que o receptor do testemunho já possui. Uma vez que esses pontos tenham sido apreciados, podemos entender o papel essencial do testemunho na aquisição de conceitos e na aprendizagem da linguagem. Pois, se o conhecimento conceitual e linguístico não pudesse ser adquirido desse modo testemunhal elementar, nós nunca teríamos os materiais cognitivos necessários para a justificação. Esse papel primevo e elementar, por sua vez, ajuda a explicar por que o testemunho precisa tanto ser considerado como credível. Seu sucesso inicial em produzir conhecimento cedo em nossas vidas 
594 | Veritas | Porto Alegre, v. 62, n. 3, set.-dez. 2017, p. 566-585

pode, de fato, ser condição para nós inteligivelmente questionarmos esse mesmo sucesso quando aprendemos a ser céticos. ${ }^{37}$

\section{Endereço postal:}

Programa de Pós-graduação em Filosofia da PUCRS

Av. da Ipiranga, 6681, prédio 5 - Porto Alegre, RS, Brasil

Data de recebimento: 25-10-2017

Data de aceite: 03-11-2017 